\title{
Benthic diatoms on fluvial tufas of the Mesa River, berian Range, Spain
}

\section{Diatomeas bentónicas en tufas fluviales del Río Mesa, Cordillera lbérica, España}

\author{
Hugo Beraldi-Campesi', Concepcion Arenas-Abad², Luis Auque-Sanz², Marta Vázquez-Urbez² \\ and Gonzalo Pardo-Tirapu²
}

1Instituto de Geología, Universidad Nacional Autónoma de México. Ciudad Universitaria, CDMX, 04510. México
2Departamento de Ciencias de la Tierra. Universidad de Zaragoza. Zaragoza, E50009. España
e-mail: hberaldi@unam.mx

Beraldi-Campesi H., C. Arenas-Abad, L. Auque-Sanz, M. Vázquez-Urbez and G. Pardo-Tirapu. 2016. Benthic diatoms on fluvial tufas of the Mesa River, Iberian Range, Spain. Hidrobiológica 26 (2): 283-297.

\begin{abstract}
Background. The Mesa River (MR) in the Iberian Range (Spain) displays prominent, Pleistocene to present-day fluvial tufa deposits. Little of their associated microbiota has been studied to date despite the regional and historical relevance of these calcareous buildups. Goals. This paper is a preliminary exploration of the diatom (Bacillariophyta) genera associated with actively-growing tufa from 10 benthic environments along $24 \mathrm{~km}$ of the Mesa River. Methods. Brightfield microscopy, as well as consultation with specialists and specialized literature was used for taxonomic classification of diatoms. Results. We identified 25 diatom genera in three different types of sedimentary facies (porous and moss-algae rich, dense-laminated, and tufa-free gravel). Most diatoms were raphid pennate (class Bacillariophyceae), while a few were centric (class Coscinodiscophyceae) or araphid pennate (class Fragilariophyceae). They appeared as integral components of the tufa structure along with cyanobacteria and other algae and mosses. Conclusions. Together with previous studies on the hydrochemistry and sedimentology of the MR, our interpretations suggest that $\mathrm{HCO}_{3}$; $\mathrm{pCO}_{2}, \mathrm{Ca}^{2+}$, and TDIC negatively affect diatom richness and that their abundance is positively related to the presence of mosses and algae.
\end{abstract}

Key words: Benthic diatoms; freshwater tufas; Iberian Range, Spain.

\section{RESUMEN}

Antecedentes. Del Río Mesa en la Cordillera Ibérica Española destacan sus tufas fluviales, depositadas desde Pleistoceno hasta el reciente. Poco de su microbiota bentónica ha sido estudiado a pesar de la relevancia regional de estas formaciones calcáreas. Objetivos. Con el objetivo de conocer los géneros de diatomeas (división Bacillariophyta) que crecen asociados a estas tufas activas, se revisaron muestras de 10 ambientes bentónicos a lo largo de 24 kilómetros del río Mesa. Métodos. Se utilizaron técnicas de microscopia y consultas con especialistas y literatura especializada para la identificación taxonómica de las diatomeas. Resultados. Se identificaron 25 géneros de diatomeas en tres diferentes tipos de facies sedimentarias (porosa con musgo y algas, densa-laminada, y grava sin tufa). La mayoría de las diatomeas fueron pennadas y con rafe (clase Bacillariophyceae), y pocas fueron céntricas (clase Coscinodiscophyceae) o pennadas sin rafe (clase Fragilariophyceae). Estas aparecieron como componentes integrales de las tufas junto con cianobacterias, musgos y algas. Conclusiones. Estudios previos de sedimentología e hidroquímica en este río sugieren que el $\mathrm{HCO}_{3}$, $\mathrm{pCO}_{2}, \mathrm{Ca}^{2+}, \mathrm{y}$ TDIC afectan negativamente a la riqueza de diatomeas, y que su abundancia esta positivamente relacionada con la presencia de musgos y algas.

Palabras clave: Cordillera Ibérica, diatomeas bentónicas, España, tobas fluviales. 


\section{INTRODUCTION}

Diatoms are of great ecological significance for the functioning of aquatic and terrestrial ecosystems, and are useful environmental and ecological indicators (e.g. Smol \& Stoermer, 2010). They are also key oxygenic photosynthesizers and prolific producers of extracellular polymeric substances (EPS) in most benthic habitats today (Krumbein et al., 2003; Pentecost, 2005). In fluvial environments, diatoms are also key primary producers and abundant on calcareous tufas (also called spring-associated limestones) worldwide (e.g. Stevenson et al., 1996; Gradzinski, 2010). Because diatoms sequester dissolved $\mathrm{CO}_{2}$ through photosynthetic $\mathrm{C}$ fixation, which results in a shift in $\mathrm{pH}$, and because they produce large quantities of EPS that can agglutinate and accrete particles, they may play an important role in tufa formation.

The Iberian Range in Spain harbors a great variety of fluvial tufa systems that have been accumulating since the Pleistocene (VázquezUrbez et al., 2012). In particular, the Mesa River (MR) and the nearby Piedra River, have been of historical importance since ancient times (e.g. Corral-Lafuente, 2000). Despite this fact, the eukaryotic component of these ecosystems is poorly known, even though the microbial diversity of other tufas in the Iberian Range have been partially documented (Beraldi-Campesi et al., 2012).

In this paper, we aim to document the diatom genera present on substrates distributed along the Mesa River, and detect any possible relationship with environmental conditions, using sedimentary and hydrochemical variables that are known to influence tufa deposition. This preliminary report will increase our understanding of these geobiological systems and will allow comparisons with diatoms from other tufa systems and neighboring areas where diatoms have been used for monitoring environmental changes (e.g. Flor-Arnau et al., 2008).

\section{MATERIALS AND METHODS}

Environmental context of the Mesa River. The Mesa River (MR) is one of several rivers in the Iberian Range, NE Spain (Fig. 1) that display thick tufa deposits (Vazquez-Urbez et al., 2010, 2012; Auque et al., 2013). The MR is a tributary of the Jalon River that later enters the Ebro River near the city of Zaragoza (Fig. 1). It flows from southwest to northeast and cuts through Mesozoic and Tertiary rocks. Mesozoic (Lower Jurassic and Upper Cretaceous) carbonate units hold the aquifers that feed the river and are responsible for the calcium bicarbonate composition of the water. The regional climate is Mediterranean continental, with strong seasonal changes in temperature and precipitation. Mean annual precipitation varies from $\sim 20$ to $\sim 55 \mathrm{~mm}$ and occurs mostly in spring (April-May) and autumn (September-October). Mean annual air temperature varies from $\sim 5$ to $25^{\circ} \mathrm{C}\left(4-5^{\circ} \mathrm{C}\right.$ in December and January and $23-25^{\circ} \mathrm{C}$ in July). Mean discharge of the MR reaches $49 \mathrm{hm}^{3} /$ year with marked variability $\left(\sim 2 \mathrm{~m}^{3} / \mathrm{s}\right.$ in May and $\sim 1 \mathrm{~m}^{3} / \mathrm{s}$ in August; see Auque et al., 2013). Several natural springs occur along the MR, most notoriously near Mochales and Jaraba (Fig. 1). Water temperature at or close to resurgence points is rather constant through the year, about $13-14{ }^{\circ} \mathrm{C}$ in the river at site 1 (Mochales) and between $20-32{ }^{\circ} \mathrm{C}$ in the low-thermal springs near Jaraba (Pinuaga et al., 2004; Sanchez-Navarro et al., 2004). Mean underground water discharge in Jaraba is also constant through the year (570 to $647 \mathrm{l} / \mathrm{s}$; Pinuaga et al., 2004). During dry seasons, the river discharge depends mainly on underground in puts (Auque et al., 2013). All these climatic and physicochemical variables drive the overall process of calcite precipitation.
Facies characterization. Different depositional environments were characterized as sedimentary facies based on the type of substrate (in plan view and cross section), water depth, water flow, and type of flora (according to the main component on the surface: mosses, algae, cyanobacteria).

Diatom sampling and identification. Ten sites distributed along the MR (Fig. 1, Table 1) were selected according to bed configuration, sedimentary facies, and physical parameters (e.g. slope, depth, and water velocity; see below), representing the main sub-environments in the river. Sites ranged from empty grounds and gravel beds, to areas densely populated by plants, bryophytes, and macroscopic colonies of algae and cyanobacteria.

At each site, 3 to 5 pieces $\left(\sim 1-3 \mathrm{~cm}^{3}\right)$ of the soft, recently-formed tufa surface were cored from limestone tablets previously placed at each site (see Vazquez-Urbez et al., 2010 for explanation), and combined into a single sample. Combined samples were immediately stored in a $20 \%$ ethanol-formalin solution for transport to the laboratory and further frozen at $-10^{\circ} \mathrm{C}$ until inspected under a microscope.

For microscopic observations of diatom frustules, tufa $\left(\mathrm{CaCO}_{3}\right)$ fragments were dissolved in a $50 \% \mathrm{HCl}$ solution, washed with distilled water in $50 \mathrm{ml}$ vials, and centrifuged to obtain a pellet. Pellets were washed in distilled water and centrifuged many times before aliquots were taken for observation. This was done on a brightfield, phase-contrast, and dark-field microscope (Olympus BH2) equipped with an Olympus DPII digital camera. Abundance of different genera per sample was noted but not quantified, as frustule counts could be highly biased by this method without exhaustive sampling of larger areas. Observations per sample were concluded when no new morphotypes were discovered in the aliquots. All identifications were made upon comparisons with the literature (Hustedt, 1930; Smith, 1950; Bourrelly, 1968; Round et al., 1990). Taxonomic names were updated from the Algaebase database (Guiry \& Guiry, 2015). Statistical analyses (Poisson regression, etc.) were processed for hydrochemical data using the R statistical software (R Core Team, 2014).

\section{RESULTS}

Diatom genera distribution. A total of 25 diatom genera were detected in the 10 studied sites (Table 1; Figs 2-3). Most of them were pennate and only two were centric (Class Coscinodiscophyceae, Melosira Agardh and Biddulphia Gray; Table 1). Not all the identified genera were present at all sites. In general, the number of diatom genera increased from sites 1 through 4, oscillated from sites 5 to 8 , and abruptly decreased at sites 9 and 10 (Table 1).

Among the pennate diatoms, 3 genera were araphid (class Fragilariophyceae) and 20 were raphid (class Bacillariophyceae; Fig. 4). Diatom genera are presented in Fig. 4 according to their frequency of appearance in the samples, from bottom (frequent) to top (rare); the most frequent genera were: Amphora Ehrenberg ex Kützing, Cocconeis Ehrenberg, and Navicula Bory de Saint-Vincent 1822 (Figs 2-3), which were detected in 7 sampling sites. Cymbella Agardh and Diatoma Bory de St-Vincent (Fig. 2) followed in frequency and were detected in 6 sites. Gyrosigma Hassall and Rhoicosphenia Grunow (Figs 2-3) were present in 5 sites. Genera present in 4 or less sites (Fig. 4; Table 1) were Achnanthidium Kützing, Gomphonema Ehrenberg, Stauroneis Ehrenberg, Denticula Kützing, Gomphoneis Cleve, Meridion Agardh, Nitzschia Hassall, Synedra Ehrenberg, Aneumastus Mann et Stickle, 
Table 1. Genera of benthic diatoms found along the Mesa River. Presence is indicated by ' $X$ '. Photos of each genus are shown in Figs 2-3. Facies: $\mathrm{A}=$ moss-dominated, porous tufa; $\mathrm{B}$ = dense, laminated tufa; $\mathrm{C}$ = tufa free gravel. See text for sedimentary facies details. Richness is expressed as the number of diatom genera found in the samples.

\begin{tabular}{|c|c|c|c|c|c|c|c|c|c|c|c|c|c|c|c|}
\hline & \multicolumn{15}{|c|}{ Latitude / Longitude } \\
\hline & 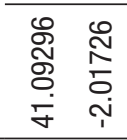 & 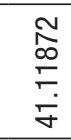 & 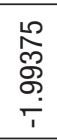 & $\begin{array}{l}\text { ? } \\
\stackrel{+}{0} \\
\stackrel{+}{+}\end{array}$ & 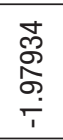 & 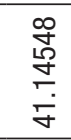 & 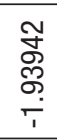 & 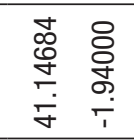 & 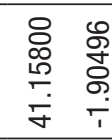 & 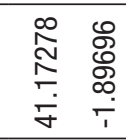 & 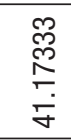 & 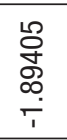 & 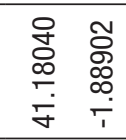 & 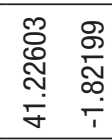 & $\begin{array}{l}\mathscr{0} \\
\text { 产 } \\
\text { 문 }\end{array}$ \\
\hline SITE & 1 & 2 & & 3 & & 4 & & 5 & 6 & 7 & 8 & & 9 & 10 & \\
\hline FACIES ${ }^{a}$ & C & $B$ & & A & & A & & $A / B$ & A & $A / B$ & $A / B$ & & C & C & \\
\hline GENUS & & & & & & & & & & & & & & & \\
\hline Achnanthidium & & & & $x$ & & $x$ & & & $x$ & & $x$ & & & & $2 A$ \\
\hline Amphora & & & & $x$ & & $x$ & & $x$ & $x$ & $x$ & $\mathrm{x}$ & & $x$ & & $2 B$ \\
\hline Aneumastus & & & & & & & & & $x$ & & & & & & $2 \mathrm{D}$ \\
\hline Biddulphia & & & & & & & & & & & & & & $x$ & $2 \mathrm{E}$ \\
\hline Cavinula & & & & & & $x$ & & & & & & & & & $2 \mathrm{~F}$ \\
\hline Cocconeis & & $x$ & & $\mathrm{x}$ & & & & $x$ & $x$ & $x$ & $\mathrm{x}$ & & & $x$ & $2 \mathrm{G}, \mathrm{H}$ \\
\hline Cosmioneis & & & & & & & & & $x$ & & & & & & $2 \mathrm{C}$ \\
\hline Cymbella & & $x$ & & & & $x$ & & & $x$ & $x$ & $x$ & & $x$ & & $21, \mathrm{~J}$ \\
\hline Denticula & $\mathrm{x}$ & & & & & $x$ & & & & & & & & & $2 \mathrm{~K}$ \\
\hline Diatoma & $\mathrm{x}$ & $x$ & & $x$ & & $x$ & & & $x$ & & $x$ & & & & 2L, M \\
\hline Diatomella & & & & $\mathrm{x}$ & & & & & & & & & & & $2 \mathrm{~N}$ \\
\hline Gomphoneis & & & & & & $x$ & & & & & $x$ & & & & 20 \\
\hline Gomphonema & & & & $x$ & & & & $x$ & $x$ & $x$ & & & & & $3 A, D$ \\
\hline Gyrosigma & & & & & & $x$ & & $x$ & $x$ & $x$ & $x$ & & & & $3 B$ \\
\hline Melosira & $x$ & & & & & & & & & & & & & & $3 C$ \\
\hline Meridion & & $x$ & & & & & & & $x$ & & & & & & \\
\hline Navicula & & $x$ & & $x$ & & $x$ & & $x$ & $x$ & $x$ & $x$ & & & & $3 E, F, H$ \\
\hline Nitzschia & & & & $x$ & & & & & & & $x$ & & & & $3 G$ \\
\hline Pinnularia & & & & & & & & & & & $x$ & & & & \\
\hline Placoneis & & & & & & & & & $x$ & & & & & & 31 \\
\hline Pleurosigma & & $x$ & & & & & & & & & & & & & $3 \mathrm{~J}$ \\
\hline Rhoicosphenia & & $x$ & & $x$ & & & & $x$ & $x$ & $x$ & & & & & $3 \mathrm{~K}, \mathrm{~L}$ \\
\hline Stauroneis & & $x$ & & $x$ & & $x$ & & & & & & & & & $3 \mathrm{M}$ \\
\hline Surirella & & & & & & & & & & & $x$ & & & & $3 N$ \\
\hline Synedra & & & & & & $x$ & & & & & $x$ & & & & 30 \\
\hline RICHNESS & 3 & 8 & & 10 & & 11 & & 6 & 13 & 7 & 12 & & 2 & 2 & \\
\hline
\end{tabular}

Biddulphia S. F. Gray, Cavinula Mann et Stickle, Cosmioneis Mann et Stickle, Diatomella Greville, Melosira C. Agardh, Pinnularia Ehrenberg, Placoneis Mereschkowsky, Pleurosigma Smith, and Surirella Turpin (Table 1; Figs 2- 3).

Although Cyanobacteria were visibly conspicuous on the tufa substrate, our samples rendered few specimens (Microcystis, Gloeocapsa, and Nostoc). Nevertheless, other cyanobacteria are known to exist at this river (Beraldi-Campesi et al., 2012). Algae within the Chlorophyta (Cladophora, Closterium, and Spirogyra), the Charophyta (Coleochaete), the Rhodophyta (Batrachospermum) and the Xanthophyta (Vaucheria), were commonly observed as part of the benthic microflora of the MR and found in our samples as well (some examples are shown in Figs 5 and 6). All these organisms were forming large, macroscopic colonies on the tufa, non-calcified submerged rocks, or on plant debris. Among these, Cladophora was ubiquitous, and its filaments were usually coated with thick layers of calcite (Figs 5K-N).
From the collected samples and field observations we could see that diatoms were especially abundant on algae and on mosses, which covered most of the benthic surfaces together with cyanobacteria. For instance, colonies of Amphora, Cocconeis, Diatoma, Melosira, and Symploca were found growing preferentially where chlorophyceans (e.g. Coleochaete, Spirogyra) were most abundant. The most conspicuous diatom genus in our survey, Cocconeis, was also epiphytic on other diatoms, green algae, and cyanobacteria (Biddulphia, Cladophora, and Nostoc, respectively), on which calcification (micritic coatings) was visually pervasive. The stalk-forming Rhoicosphenia and Gomphonema were also conspicuous on filamentous algae and mosses, where also micritic particles accumulated around them. These biotic interactions were not exclusive, and mixtures could be seen at sites where chlorophyceans, rhodophyceans, and xanthophyceans (all carrying epiphytic diatoms) were growing together in large patches on the substrate. 


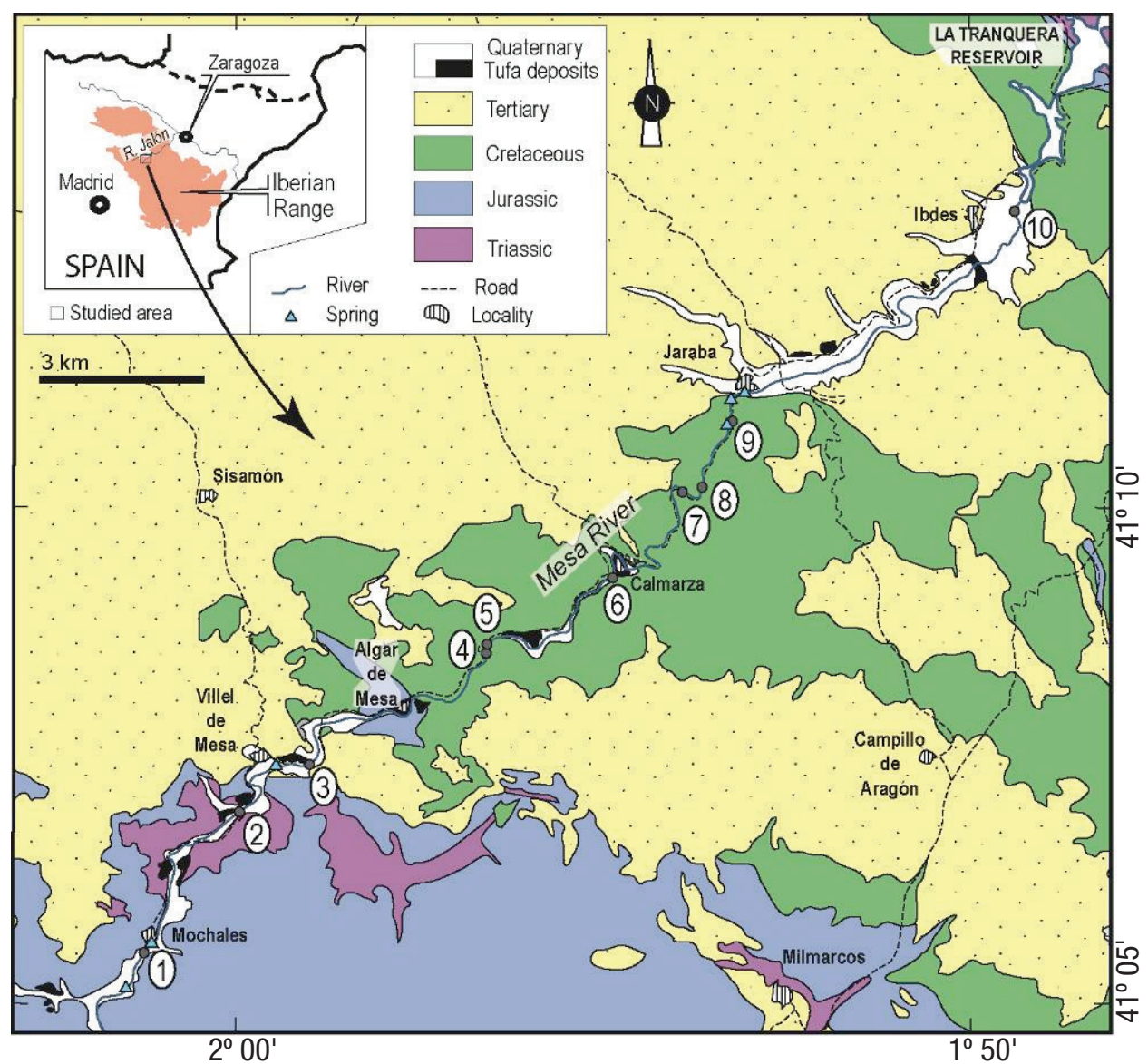

Figure 1. Geographic distribution of sampling sites (numbered dots) and geological context of the Mesa River. The river flows from SW to NE.

Table 2. Characteristic sedimentary facies found in the sampled sites along the Mesa River.

\begin{tabular}{lcccc}
\hline \multicolumn{1}{c}{ Depositional subenvironment } & $\begin{array}{c}\text { Water velocity } \\
(\mathrm{cm} / \mathrm{s})\end{array}$ & $\begin{array}{c}\text { Depth } \\
(\mathrm{cm})\end{array}$ & $\begin{array}{c}\text { Facies } \\
\text { code }\end{array}$ & \multicolumn{1}{c}{ Sedimentary facies } \\
\hline $\begin{array}{l}\text { Small, generally stepped jumps, rapids, } \\
\text { subhorizontal platforms and irregular } \\
\text { horizontal beds with cobbles. }\end{array}$ & $70-110$ & $9-25$ & A & $\begin{array}{l}\text { Mostly spongy tufa: mats of filamentous algae, mosses, cyano- } \\
\text { bacteria and diatoms, poorly coated with calcite. Lamination is } \\
\text { commonly absent. }\end{array}$ \\
$\begin{array}{l}\text { Small jumps, rapids and subhorizontal } \\
\text { floors and, less commonly, in irregular } \\
\text { horizontal beds with cobbles }\end{array}$ & $70-120$ & $10-15$ & B & $\begin{array}{l}\text { Laminated tufa made of calcite tubes formed around cyano- } \\
\text { bacterial filaments; mucilaginous substance, bacterial rods and } \\
\text { cocci bodies, along with diatoms appear associated. Other algal } \\
\text { components may be seen. }\end{array}$ \\
$\begin{array}{l}\text { Gravel and cobble beds influenced by } \\
\text { groundwater inputs }\end{array}$ & $60-120$ & $10-30$ & C & $\begin{array}{l}\text { Rare filamentous algae and mosses, diatoms, cyanobacterial } \\
\text { biofilms, some mollusks, insect nests and annelid tubes. Small } \\
\text { clumps of calcite irregularly distributed on algae and mosses. }\end{array}$ \\
\hline
\end{tabular}

Environmental context and sedimentary facies. The tufa deposits we studied displayed different sedimentary characteristics (e.g. variations in thickness, porosity, and presence/absence of lamination), depending on the local environmental conditions (water flow velocity, depth, slope, luminosity, shade, etc.) and the associated flora (e.g. algae, bryophytes, etc.). In sites with rapid calcification, these floras seemed to be quickly entombed within the tufa structure. Diatoms were notorious within calcified communities and seemed to be integral components of the tufa structure (Fig. 7). Three main sedimentary facies were identified along the MR (see below). Two facies (A and B, see Table 2) developed on small waterfalls and rapids with relatively shallow and fast-flowing water $(\sim 100 \mathrm{~cm} / \mathrm{s})$, and have been characterized for rapid tufa formation ( 1.3 cm/yr; Vázquez-Urbez et al., 2010). A third facies (C), consisted mainly on gravel-dominated grounds, with poor or no carbonate deposition (Table 2). Facies A and B often occurred together in lit areas (e.g. sites 4, 5, 6, and 8), and were thicker than in shady ones (e.g. sites 2 and 7; See Fig. 1 and Table 1 for location of sites). The diatom genera distribution within each of these facies is reported in Table 1. Facies descriptions are as follows: 


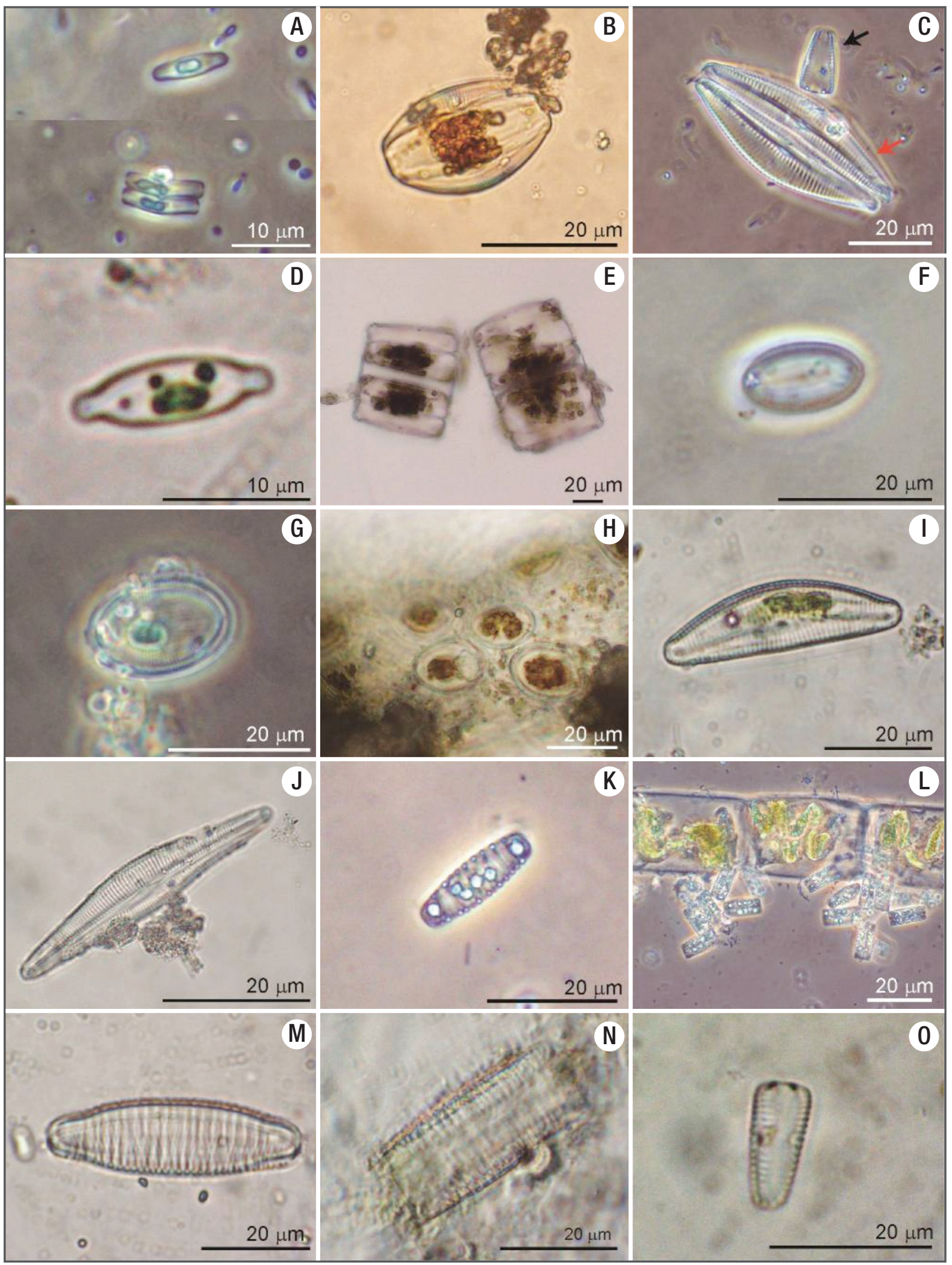

Figures 2A-0. Diatom genera found in the Mesa River. A) Achnanthidium. B) Amphora. C) Cymbella (red arrow) and Gomphonema (black arrow). D) Aneumastus or Cosmioneis. E) Biddulphia. F) Cavinula. G) Cocconeis. H) Cocconeis on algal filament. I-J) Cymbella. K) Denticula. L) colonies of Diatoma on algal filament. M) Diatoma. N) Diatomella. 0) Gomphoneis. 


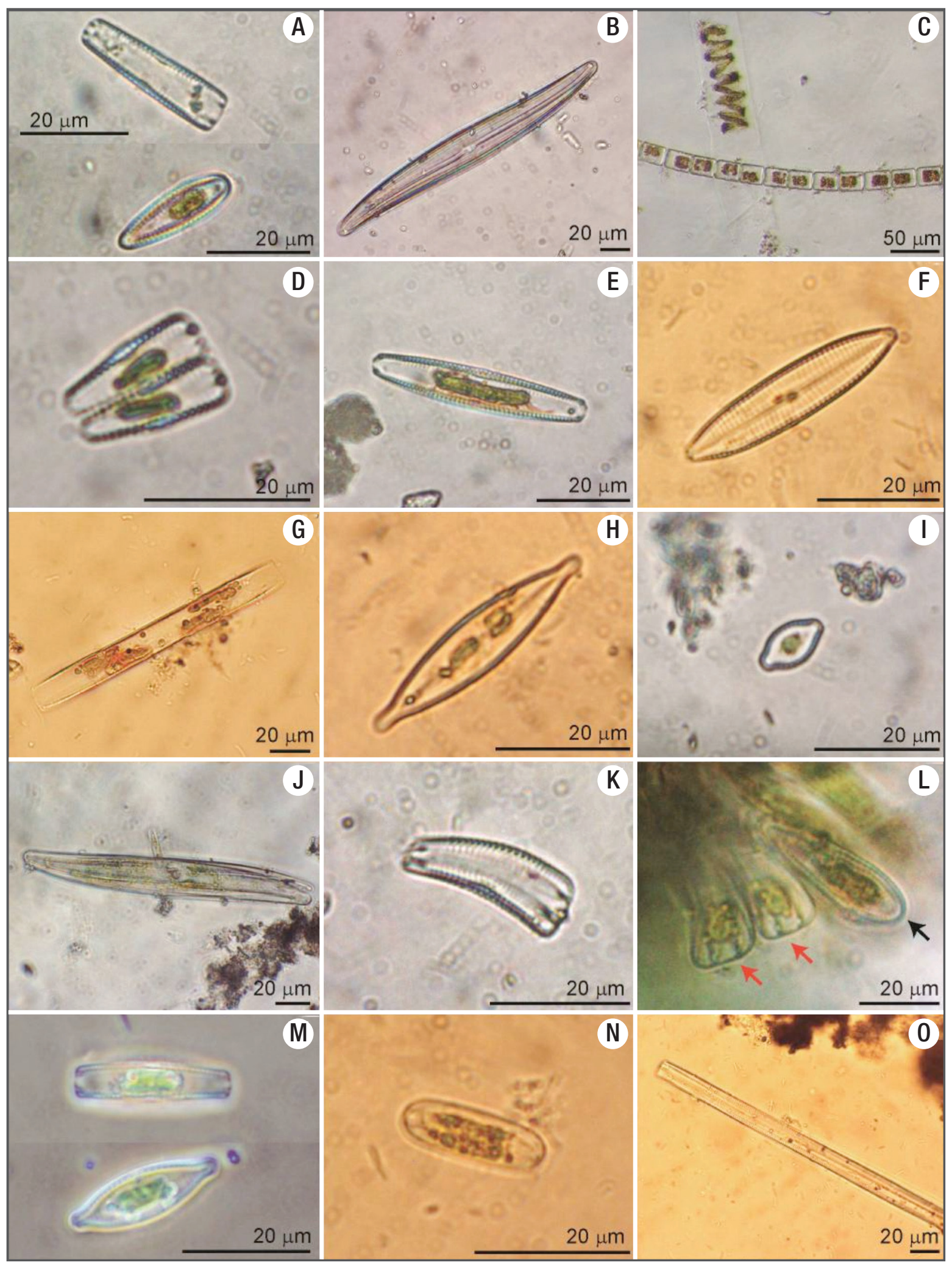

Figures 3A-0. Diatom genera found in the Mesa River. A) Gomphonema. B) Gyrosigma. C) Melosira next to an algal filament. D) Gomphonema. E-F) Navicula. G) Nitzschia. H) Navicula. I) Placoneis or Cosmioneis. J) Pleurosigma. K) Rhoicosphenia. L) periphytic Rhoicosphenia in perivalvar view (red arrow) and valvar view (black arrow). M) Stauroneis. N) Surirella. 0) Synedra. 
Facies $A$ : This was the most widespread facies (Figs 8A-B) consisting of soft, very porous deposits, composed of completely or partially coated (calcified) filamentous cyanobacteria, and/or filamentous, siphonous, and parenchymatous algae (e.g. Spirogyra, Vaucheria, and Batrachospermum respectively), and bryophytes (Fig. 8B). Filamentous algae and mosses were visually more abundant than cyanobacteria in this facies. Both micrite and spar calcite crystals were present on these organisms, and pores and voids were sometimes filled with calcite, as in other examples of the same area (Arenas et al., 2000), indicating relatively quick diagenetic processes. A variety of benthic diatoms were observed as periphyton on bundles of filamentous algae in this facies (Fig. 7).

Facies $B$ : This facies consisted of hard and dense, calcitic, laminated deposits (also called stromatolitic tufa; Figs. 8C-D). Cyanobacteria were more common than algae in this facies. Sub-millimeter to $\mathrm{mm}$ thick laminae were composed of calcite tubes forming palisades and bunches subperpendicular to the surface. The tubes were hollow (inner diameter $\sim 7 \mu \mathrm{m}$ ) and consisted of $\sim 5-7 \mu \mathrm{m}$-thick micrite and spar calcite walls (shown in cross section in Fig. 7B), and were linked by calcite crystals and mucilaginous substance, on which diatoms were attached. The size and morphology of the tubes suggest that filamentous microbes acted as templates for the nucleation of calcite.

Facies $C$ : This facies consisted of poorly calcite-coated substrates (Figs $8 \mathrm{E}-\mathrm{F}$ ) in less shallow water. The bedrock was dominated by gravel and cobble deposits on gently steep or quasi-horizontal beds, in medium to high-velocity flow conditions $(60-100 \mathrm{~cm} / \mathrm{s})$. These sites were close to springs and thus received variable groundwater inputs. Thin patches of cyanobacteria-dominated communities, scarce filamentous algae, mollusks, and some insect nests were common biotic features of these facies. These components were almost devoid of calcite impregnations or coatings (e.g. sites 1, 3, 9, and 10).

\section{DISCUSSION}

Diatoms and tufa formation. Pennate diatom genera were abundant and had a wide distribution within the MR samples, while centric diatoms were represented only by two genera. This has also been observed in other tufas and travertines of the world (Pentecost, 2005; Brinkmann et al., 2007; Arp et al., 2010; Gradzinski, 2010).

Most of the identified diatom genera have been reported from other freshwater streams of the world (Pentecost, 2005; Brinkmann et al., 2007; Arp et al., 2010). Among these, genera such as Amphora, Cocconeis, and Navicula had the widest distribution in the MR samples. In contrast, Aneumastus, Biddulphia, Cavinula, Cosmioneis, Diatomella, Melosira, Pinnularia, Placoneis, Pleurosigma, and Surirella were only present in one sample from the MR. Only 17 genera identified here (Achnanthidium, Amphora, Cocconeis, Cymbella, Denticula, Diatoma, Gomphoneis, Gomphonema, Gyrosigma, Melosira, Meridion, Navicula, Nitzschia, Pinnularia, Rhoicosphenia, Surirella, and Synedra), corresponded to 68 genera found in the Ebro basin (Flor-Arnau et al., 2008), which is a neighboring drier basin to the north of the Iberian Range. Even though our study was limited for close comparisons by the taxonomic resolution, it seems that these tufa environments bear a unique 'oasis' of diatom genera within the region. Nevertheless, complemen-

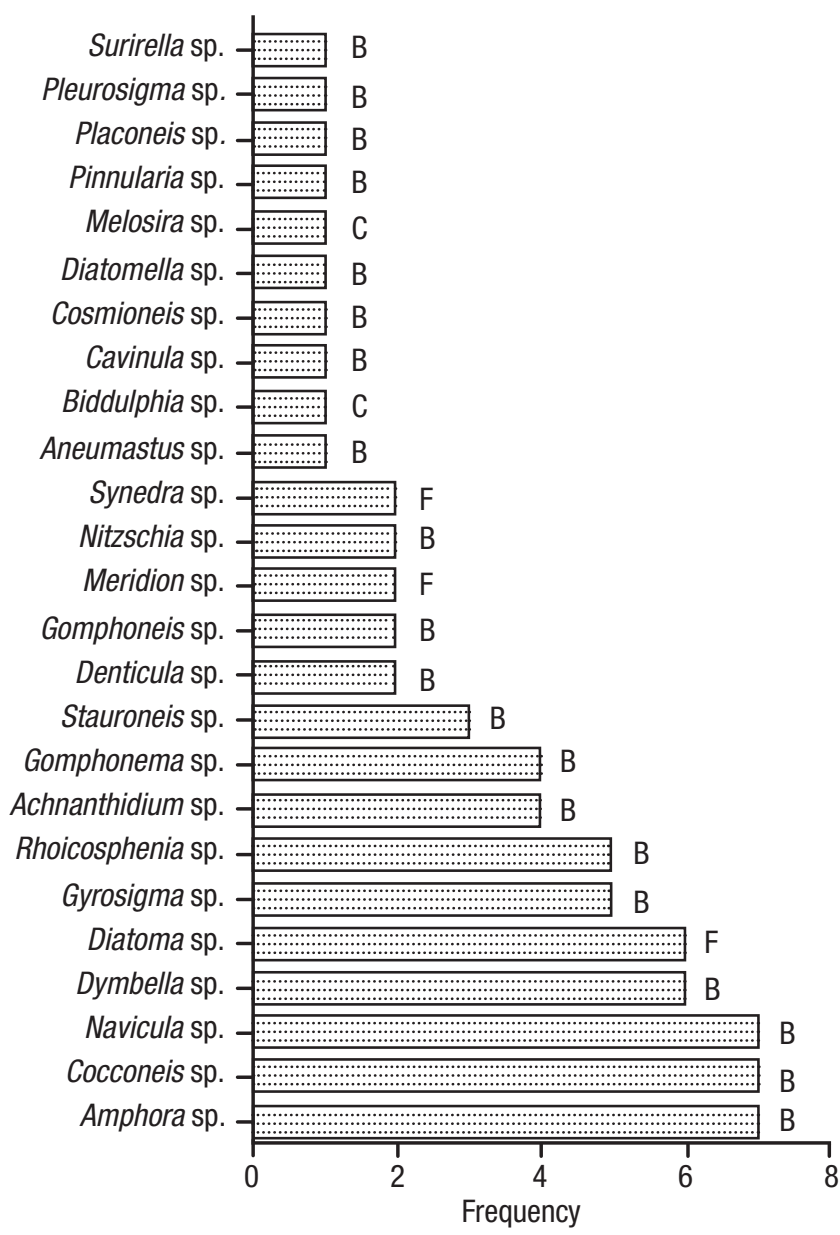

Figure 4. Frequency distribution of diatom genera from 10 sampling sites. $B=$ Bacillariophyceae; $\mathrm{F}=$ Fragilariophyceae; $\mathrm{C}=$ Centric.

tary molecular fingerprinting studies would help to refine the identity and distribution of diatoms in these areas.

In the MR, $80 \%$ of the pennate diatoms displayed raphe, which is related to the motile benthic habit of the Bacillariophyceae (Round et al., 1990; Chafetz et al., 1991; Arp et al., 2010). A motile capability would perhaps favor pennate raphids over the non-motile pennate araphids in places where continuous and fast carbonate precipitation occurs ( 5 $\mathrm{mm} / \mathrm{yr}$ on average and up to $13 \mathrm{~mm} / \mathrm{yr}$ in some places; see VázquezUrbez et al., 2010). It is likely that the fast carbonate deposition is in part responsible for changes in growth speed, coverage, and distribution of benthic microorganisms, including diatoms. It is reasonable to think that eukaryotic and prokaryotic communities at the surface of these (visually abundant) tufas, are very dynamic, in part due to the environmental pressure of permanent calcification and entombment. Another ecological alternative observed in non-calcareous, siliciclastic environments is that the distribution of motile versus non-motile diatoms may be due to their growth habits, in which non-motile diatoms tend to form bulk colonial aggregates, while motile diatoms are more widely dispersed (Hudon \& Legendre, 1987). 


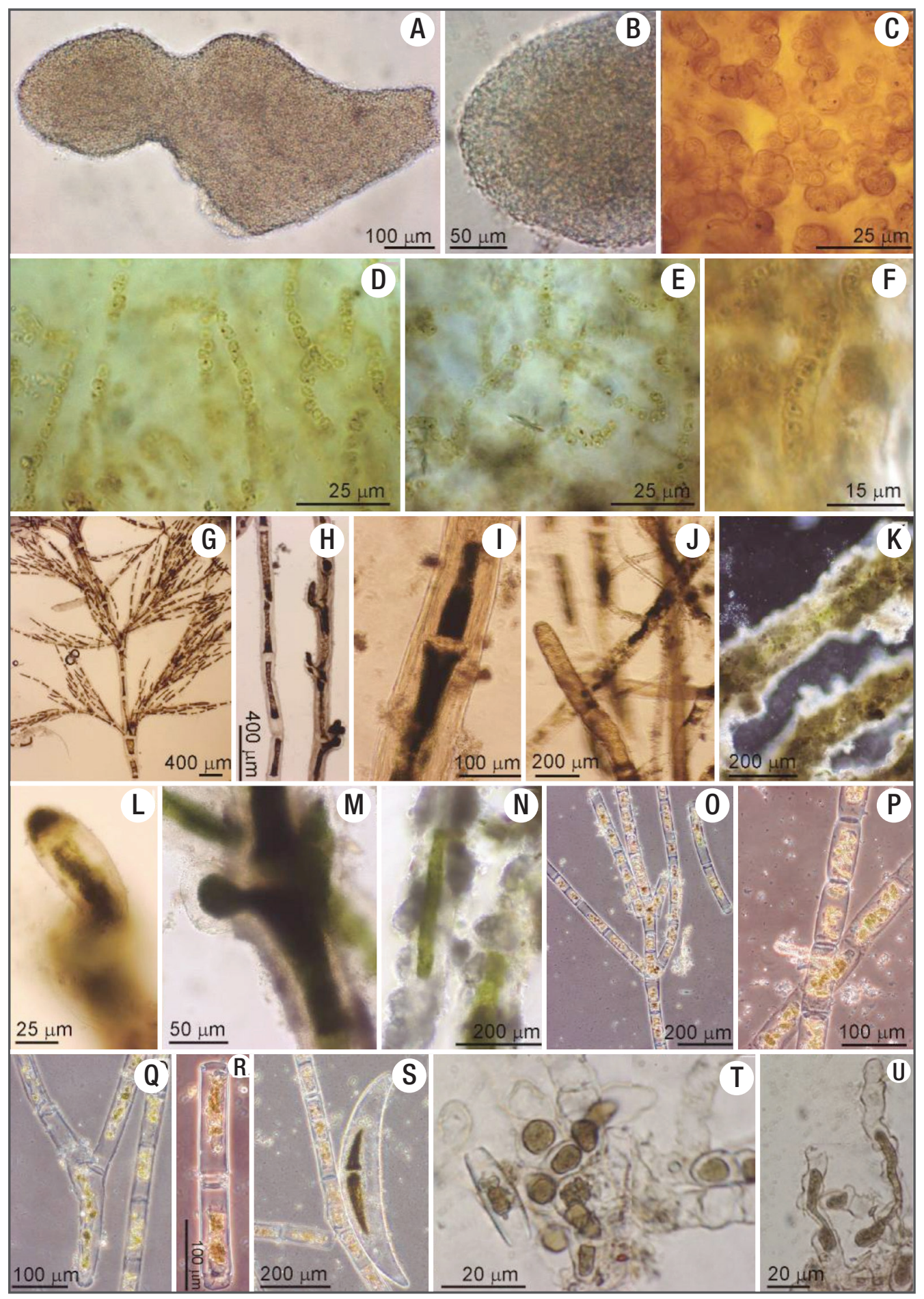

Figures 5A-U. Examples of benthic organisms co-existing with diatoms. A) Colony of the planktonic cyanobacterium Microcystis, although usually planktonic, these colonies become attached to the substrate at shallow exposures of the tufa. B) Close up of A showing the mucilage cover around the entire colony, which keeps it from disaggregating. C) Colony of the cyanobacterium Gloeocapsa showing stratified sheaths in a dense mucilaginous matrix. D-E) Arrangement of trichomes within a colony of Nostoc. F) Single filament within a Nostoc colony, around which abundant mucilage has been secreted. G) Ramified trichome of Cladophora. H) Filaments of Cladophora with and without growing bulbs. I) Zoom on a filament of Cladophora to appreciate cellular details and sparse calcite adhered to its sheath. J) Cladophora mingled with Vaucheria filaments. K) Filaments of Cladophora completely coated with calcite. L) Zoom on a Cladophora bulb without calcitic coat. M) A bulb of Cladophora in the process of being coated with calcite. N) Partially-coated Cladophora filaments. O-R) Unbranched, overlapped filaments of Spirogyra This alga was rarely found coated with calcite. S) Large cell of Closterium next to a Spirogyra filament. T) Basal cells of a Coleochaete colony. U) Terminal cells of a Coleochaete colony. 
Diatoms can be seen in fresh fractures of recently-formed tufa (upper $10 \mathrm{~cm}$ of actively-growing tufa) and likely play a role in the mediation of these sedimentary structures by enhancing carbonate precipitation and influencing the morphological development of the structure. Tufa formation can go on abiotically through $\mathrm{CO}_{2}$ outgassing (Merz-Prei $\beta$ \& Riding, 1999; Chen et al., 2004; VazquezUrbez et al., 2010), but some organisms (bacteria, algae, fungi, bryophytes, plants) can mediate tufa development by a) trapping and binding particles with accretionary movement in and on a sticky, EPS-rich surface; b) serving as nucleation sites where calcite crystals accommodate according to the pre-existing 3D arrangement of the colonies, which develops particular structures and microfabrics; c) by removing dissolved $\mathrm{CO}_{2}$ during photosynthesis; and d) by altering the local equilibrium in favor of carbonate precipitation (Rogerson et al., 2008; Pedley et al., 2009; Dittrich \& Sibler, 2010; Shiraishi et al., 2008, 2010).

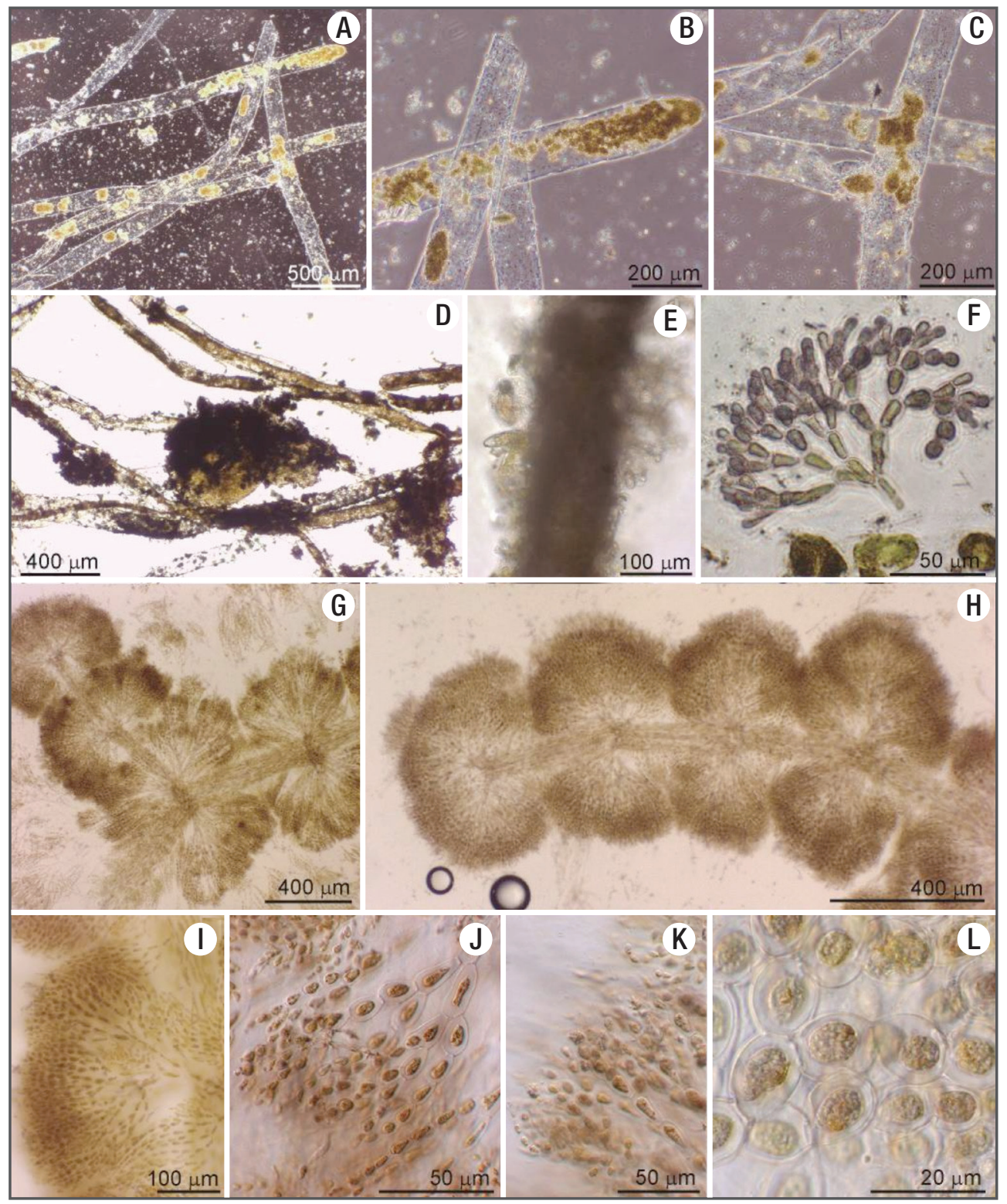

Figures 6A-L. Examples of benthic organisms co-existing with diatoms. A) Filaments of Vaucheria. B-C). Zoom on filaments of Vaucheria showing details of the cellular contents. Note almost no calcitic coatings around them. D) Filaments of Vaucheria in the process of being coated with calcite. E) Filament of Vaucheria completely coated with calcite and epiphytic diatoms (Gomphonema) on its surface. F) Fragment of a Batrachospermum terminal cells. G-H) Cellular arrangement of Batrachospermum showing a central stem and lateral branches. I-L) Cellular morphology and arrangement within a macroscopic branch (shown in G-H) of Batrachospermum. 


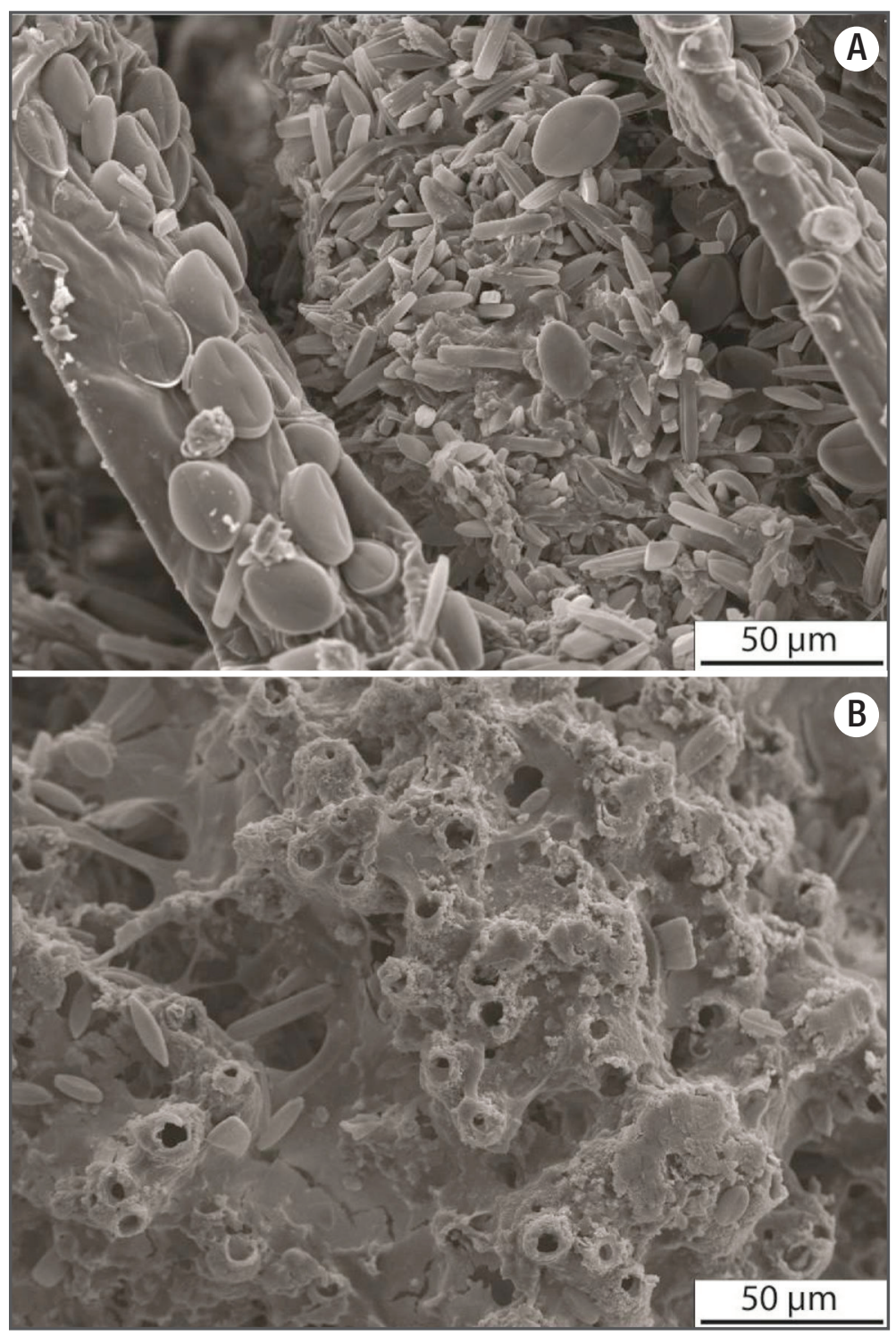

Figures 7A-B. Scanning Electron Microscope images of samples from facies A and B. A) facies A showing calcified filaments of green algae and mosses covered with diatoms. Note large Cocconeis Frustules on an algal filament (to the left). B) facies B showing calcite tubes (empty cyanobacterial sheaths) found within dense, laminated facies. Note the abundant exo-polysaccharides (EPS) filling interstitial spaces, where diatoms resembling Aneumastus or Cosmioneis are also present.

SEM and light microscopy observations, however, have shown that diatoms of the MR are not necessarily coated with calcite, despite being attached to algae or solid substrates where micrite and calcite platelets are part of the bulk mass (Figs 6E, 7). Although diatoms (e.g. Cocconeislike morphologies; Fig. 7) can be seen embedded in the already-formed tufa, they seem to avoid calcite precipitation directly on their extracellular surroundings. This phenomenon has been observed in other similar substrates as well (Merz-Prei $\beta$ \& Riding, 1999; Arp et al., 2001; Gradzinski, 2010). This is perhaps because of the composition of their EPS, but could also be derived from a constant EPS replacement given their motile nature, in contrast with cyanobacteria and green algae that calcify in situ given their sessile nature. In this regard, it should be further determined if combined factors, including seasonality, also influence the way in which calcite precipitates around microbial coIonies. For instance, poor precipitation on diatom biofilms during the winter (e.g. Arp et al., 2001) may reverse during the summer when there is a much higher rate of calcite precipitation (Vázquez-Urbez et al., 2010). Carbonate precipitation may also change due to variations in community composition, which in turn influence the amount and type of organic substrates on which $\mathrm{CaCO}_{3}$ can bind and start calcite nucleation (e.g. Lebron \& Suarez, 1996). Although determining the particular role of the MR diatoms in the processes of tufa formation requires additional studies, the biotic components in the river certainly contribute to developing particular structures and textures, and determine much of the volume and porosity of the MR and other tufa deposits of the world (Rogerson et al., 2008; Pedley, 2009; Pedley et al., 2009; Gradzinski, 
2010; Shiraishi et al., 2010; Vázquez- Urbez et al., 2010). Usually, the organisms that produce more biomass exert a major influence on the inner texture and fabric developed in tufas. This is evident in soft, mossrich, porous tufa that can grow $>10 \mathrm{~mm} / \mathrm{year}$ in these rivers, compared to $5 \mathrm{~mm} /$ year or less in microbial, biofilm-dominated tufas (VázquezUrbez et al., 2010).

Interestingly, this effect of the biology on the inner texture of the tufas also occurs in other chemical sedimentary deposits where microbes are present (e.g. travertines, stromatolites, thrombolites, and silica sinters; see Cady \& Farmer, 1996; Jones \& Renaut, 1996; Jones et al., 1998; Riding, 2000; Konhauser et al., 2001; Pentecost, 2005; Jones et al., 2007, 2008). In the MR, the presence of diatoms frustules within the tufa structure (and within most chemical sedimentary deposits), likely influences the diagenetic processes of lithification and remineralization early after lithification (which is quite fast in chemical deposits). Other means of influence may involve the amount of organic matter they contribute to the system, a part of which is expected to be entombed within the tufa structure (Fig. 7). It remains unclear, however, how this organic matter and silica frustules affect the diagenetic processes of the tufa over time. Nevertheless, fluids and minerals likely evolve through time and alter the primary structure of the tufa, as well as the amount and composition of organic matter and metabolic byproducts, along with the recycling of the opaline silica frustules trapped within the sedimentary structure during intermediate stages of tufa formation (e.g. Kastner et al., 1977; Hein et al., 1978; Barker et al., 1991; Michalopoulos et al., 2000).

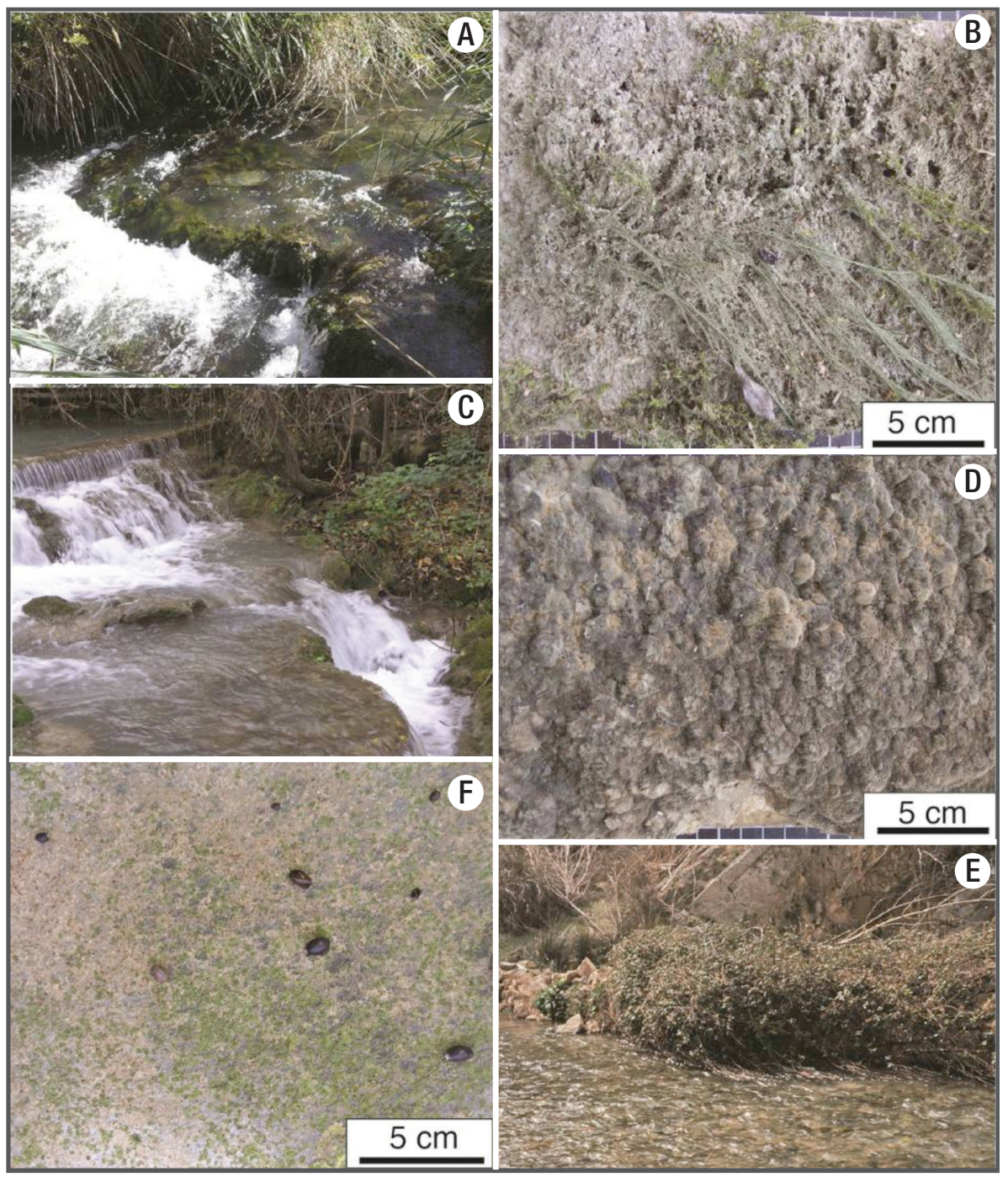

Figures $8 \mathrm{~A}-\mathrm{F}$. Field view of the major sedimentary facies distributed along the Mesa River, and close ups of limestone tablets recovered at representative sites with those facies. A-B) facies A (moss- and algal-dominated, soft and highly porous sediment) at site 4. C-D) facies B (dense, laminated tufa) at site 2. E-F) facies C (graveldominated, poor tufa development) at site 9 . Note snails of different sizes grazing on primary producers, which erode the tufa surface. 
Sedimentary and hydrochemical variables. Data from previous studies on the hydrochemistry of the MR (Auque et al., 2013) were used for correlation with the presence of diatom genera using an Anova Poisson regression (Fig. 9). Some of the physicochemical variables (alkalinity $\left[\mathrm{HCO}_{3}^{-}\right], \mathrm{K}^{+}, \mathrm{Ca}^{2+}, \mathrm{pCO}_{2}$, and TDIC) varied negatively and significantly with respect to diatom genera richness, while $\mathrm{pH}$ and $\mathrm{CaCO}_{3}$ were also significant but varied positively (Fig. 9). In sites with low $(<5)$ number of genera present (sites $1,9,10$ ), these variables attained high values, whereas in sites with a higher number of genera $(>5)$ their values were low, especially sites 6 and 8 , which had the highest richness of all.

The number of genera present in samples from the beginning and the end of the river was low, in sites where springs and human establishments (especially the largest, Jaraba and Ibdes) also occur (Fig. 1). Nevertheless, other sites close to (less populated) towns (e.g. sites 3 and 6) had a relatively high numbers of diatom genera, causing uncertainty as to whether human establishments had a direct influence on diatoms or not. Further considerations on the degree of human activity in these towns and its impact on the quality of nearby water, including outputs from agriculture and other activities, should be assessed before assuming a negative correlation between these two variables.

In the MR, deep-underground, somewhat thermal, and cool-water surface processes drive calcite precipitation at a large scale. Calculated saturation index (SIc) for calcite were consistent with abundant tufa formation with values above 0.77 (Auque et al., 2013) that seem sufficient to overcome the carbonate kinetic precipitation barrier (e.g. Jacobson \& Usdowski, 1975; Dandurand et al., 1982; Suarez, 1983; Drysdale et al., 2002; Malusa et al., 2003; Lojen et al., 2004). The springs along the river (sites 1, 3 and 9) were the exception, as the Slc decreases below 3.20 (Auque et al., 2013) and almost no tufa formation took place at those sites (only facies $C$ develops there). These sites were directly affected by nearby groundwater discharges (especially at the
Jaraba thermal waters) at equilibrium or near equilibrium with respect to calcite. Mixing of groundwater inputs and surface water seemed to promote a clear decrease in the Slc values, as well as an increase in the $\mathrm{pCO}_{2}$ partial pressure, the $\mathrm{HCO}_{3}{ }_{3}$, and TDIC contents. Therefore, the occurrence of several groundwater discharge points along the MR is likely a main factor controlling the tufa sedimentation rates, as groundwater inputs promote the increase in the partial pressure of $\mathrm{CO}_{2}$ and the decrease in the Slc values, precluding tufa formation near those groundwater discharge points. Downstream of these points, $\mathrm{CO}_{2}$ degassing increases the Slc values and, after a certain distance, saturation index values again reach the minimum threshold for tufa formation (see Auque et al., 2013 for further details).

Furthermore, the number of diatom genera decreased with higher concentrations of $\mathrm{HCO}_{3}, \mathrm{~K}^{+}, \mathrm{Ca}^{2+}, \mathrm{pCO}_{2}$, and TDIC (Fig. 9), and increased with $\mathrm{pH}$. In this respect, higher $\mathrm{Ca}^{2+}$ and $\mathrm{HCO}_{3}{ }^{-}$concentrations in the water are assumed to derive from less $\mathrm{CaCO}_{3}$ precipitation for sites 1,9 , and 10, which coincidently record the lowest tufa deposition rates and the lowest numbers of diatom genera (Facies C). These sites were strongly influenced by groundwater inputs, which supplied dissolved $\mathrm{CO}_{2}$ to the flowing water, therefore inhibiting or lowering $\mathrm{CaCO}_{3}$ precipitation (Auque et al., 2013). The drastic decrease in numbers of diatom genera at site 9 and downstream may be influenced by the high underground discharge of the Jaraba springs (570 to $647 \mathrm{l} / \mathrm{s}$ ). By contrast, sites with high numbers of diatom genera were away from spring discharges and had different sedimentary facies. For example, in sites with higher numbers of diatom genera (sites 4, 6, and 8), soft, porous tufa with abundant calcified filamentous algae and mosses has developed (facies A; Fig. 8 A-B). In contrast, sites 5 and 7 displayed both facies $A$ and $B$, but developed in more shady areas (less photosynthetic activity), particularly site 7 . It is possible that the dominance of diatoms in places with low $\mathrm{CaCO}_{3}$ precipitation, is also influenced by their biotic

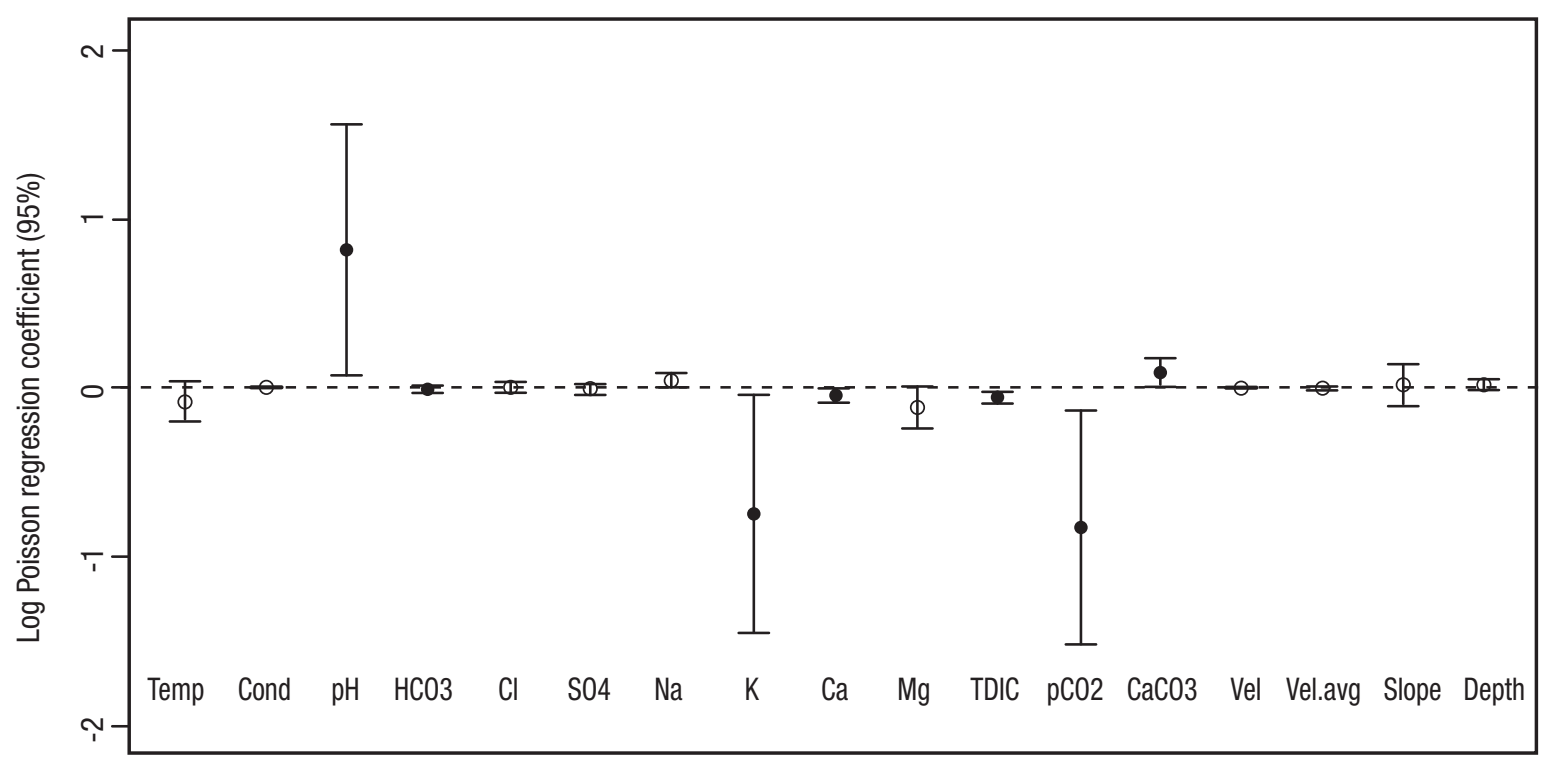

Figure. 9. Poisson regression of physicochemical data (Auque et al., 2013) and diatom richness values. Only black dots indicate variables that correlated significantly with richness. Values for $\mathrm{pH}$ and $\mathrm{CaCO}_{3}$ correlated positively. Values for $\mathrm{HCO}_{3}^{-}, \mathrm{K}^{+}, \mathrm{Ca}^{2+}, \mathrm{TDIC}$, and $\mathrm{pCO}_{2}$ correlated negatively. The log regression was constrained to the $95 \%$ confidence interval. 
interactions, such as their epiphytic habit (higher richness where mosses and algae were more abundant), which are ultimately determined by the different physical and chemical conditions at each site. Despite the wide range of environmental conditions that a single species of diatom can tolerate (e.g. Fischer, 1979; Sánchez-Castillo 1993), the hydrochemistry along the MR has remained fairly constant throughout the last decade (Auque et al., 2013). Yet for some diatom species, a wide range of environmental conditions may not significantly affect changes in morphology (Stevenson et al., 1996). Therefore, assessments based on morphological traits to the level of genera should be taken with caution when using them as proxies for interpreting past or present environmental parameters, because discrete morphological changes may not be detected to the species level. Tufas exist since ancient times (Brasier, 2011) and thus are potential paleoenvironmental reservoirs of information about the physicochemical conditions at the time of deposition (Pedley \& Rogerson, 2010), which may help us better understand the ecology of these environments through time. More studies on the diversity of the microflora living in these unique, freshwater sedimentary systems are needed. The use of biotechnological and bioinformatic tools are needed to explore such biodiversity. At least for diatoms, however, the recognition of the morphological expression of such biota should never be neglected.

\section{ACKNOWLEDGEMENTS}

We thank Sergio Cevallos-Ferriz, Antonio Altamira, Gerardo Zenteno, Elena Lounejeva, and Alexander Correa-Metrio, Institute of Geology, UNAM; Eberto Novelo Maldonado, Faculty of Sciences, UNAM; and Dr. Michal Gradzinski, Institute of Geological Sciences, Jagiellonian University, for their comments and technical support. This study was funded by projects REN2002-3575CLI and CGL2006-05063BTE of the Spanish Government and European Regional Development Funds. This is part of the Continental Sedimentary Basin Analysis Group (Aragon Government, University of Zaragoza).

\section{REFERENCES}

Appelo, C. A. J., \& D. Postma. 2005. Geochemistry, groundwater and pollution. 2nd Ed. Balkema Publisher, London. 647 p. DOI: 10.1201/9781439833544

Arenas, C., F. Gutiérrez, C. Osácar \& C. Sancho. 2000. Sedimentology and geochemistry of fluvio-lacustrine tufa deposits controlled by evaporite solution subsidence in the central Ebro Depression, NE Spain. Sedimentology 47: 883-909. D0l: 10.1046/j.13653091.2000.00329.x

Auque, L. F., P. Acero, M. J. Gimeno, J. B. Gómez \& M. P. Asta. 2009. Hydrogeological modeling of a thermal system and lessons learned for CO2 geologic storage. Chemical Geology 268: 324-336. DOI: 10.1016/j.chemgeo.2009.09.011

Auque, L. F., C. Arenas, C. Oscar, G. Pardo, C. Sancho \& M. Vázquez-Urbez. 2013. Tufa sedimentation in changing hydrological conditions: the River Mesa (Spain). Geologica Acta 11 (1): 85-102. DOI: $10.1344 / 105.000001774$
Arp, G., N. Wedemeyer \& J. Reitner. 2001. Fluvial tufa formation in the hard water creek Deinschwanger Bach (Franconian Alb, Germany). Facies 44: 1-22. DOI: 10.1007/bf02668163

Arp, G., A. Bissett, N. Brinkmann, S. Cousin, D. De Beer, T. Friedl, K. I. Mohr, T. R. Neu, A. Reimer, F. Shiraishi, E. Stackebrandt \& B. Zippel. 2010. Tufaforming biofilms of German karstwater streams: microorganisms, exopolymers, hydrochemistry and calcification. Geological Society of London, Special Publication 336: 83-118. D0I: 10.1144/sp336.6

Barker, P., F. Gasse, N. Roberts \& M. Taleb. 1991. Taphonomy and diagenesis in diatom assemblages; a Late Pleistocene palaeoecological study from Lake Magadi, Kenya. Hydrobiologia 214: 267-272. DOI: 10.1007/bf00050960

Beraldi-Campesi, H., S.R.S. Cevallos-Ferriz \& E. Chacón-BaCa. 2004. Microfossil algae associated with Cretaceous stromatolites in the Tarahumara Formation, Sonora, Mexico. Cretaceous Research 25: 249-265. D0I: 10.1016/j.cretres.2003.12.002

Beraldi-Campesi, H., C. Arenas-abad, F. Garcia-Pichel, 0. Arellano-Aguilar, L. Auque, M. Vázquez-Urbez, C. Sancho, C. Osácar \& S. Ruiz-Velasco. 2012. Benthic bacterial diversity from freshwater tufas of the lberian Range (Spain). FEMS Microbiology Ecology 80: 363-379. DOI: 10.1111/j.1574-6941.2012.01303.x

Beraldi-Campesi H. 2014. Life cycle of a Cretaceous non-marine centric diatom. Cretaceous Research 50: 89-96. D0I: 10.1016/j.cretres.2014.03.025

Bourrelyy, P. 1968. Les Algues d'eau douce. Initiation a la systematique, II: Les Algues jaunes et brunes, Chrysophycees, Pheophycees, Xanthophycees et Diatomees. Pans Editions N. Boubee \& Cie. Paris. 438 p. DOI: $10.2307 / 2258341$

BrASIER, A. T. 2011. Searching for travertines, calcretes and speleothems in deep time: Processes, appearances, predictions, and the impact of plants. Earth-Science Reviews 104 (4) 213-239. D0I: 10.1016/j. earscirev.2010.10.007

Brinkmann, N., A. Behnke, S. Bruns, K. Mohr, R. Jahn \& T. Friedl. 2007. Assessing the diversity of pennate benthic diatoms in calcifying biofilms of hard water creeks. In: Kusber W. H. \& R. Jahn (Eds.). Proceedings of the 1st Central-European Diatom Meeting. Botanic Garden and Botanical Museum Berlin-Dahlem, Freie Universitat Berlin. p. 1114. D0I: $10.3372 /$ cediatom. 102

CAdy, S. L. \& J. D. Farmer. 1996. Fossilization processes in siliceous thermal springs: Trends in preservation along thermal gradients. In: G. R. Bock \& J. A. Goode (Eds.). Evolution of Hydrothermal Ecosystems on Earth (and Mars?), CIBA Foundation Symposium No. 202 Wiley and Sons. Chichester, UK. p. 150-173. DOI: 10.1002/9780470514986. ch9

Chafetz, H. S., P. F. Rush \& N. M. Utech. 1991. Microenvironmental controls on mineralogy and habit of $\mathrm{CaC} 03$ precipitates an example from an active travertine system. Sedimentology 38: 107-126. D0I: 10.1111/j.1365-3091.1991.tb01857.x

Chen, J., D. D. Zhang, S. Wang, T. Xia0 \& R. Huang. 2004. Factors controlling tufa deposition in natural waters at waterfall sites. Sedimentary Geology 166: 353-366. D0I: 10.1016/j.sedge0.2004.02.003 
Corral-Lafuente, J. L. 2000. La génesis de la comunidad de aldeas de Calatayud, Aragón, en la Edad Media. XVI. Homenaje al Profesor Emérito Ángel San Vicente Pino, vol. 16, Departamento de Historia Medieval, Universidad de Zaragoza, Zaragoza. pp. 197-213. ISSN: 0213-2486

Cousin, S. \& E. StaCKEBRAndt. 2010. Spatial Bacterial Diversity in a Recent Freshwater Tufa Deposit. Geomicrobiology Journal 27: 275-291. DOI: 10.1080/01490450903410449

Dandurand, J. L., R. Gout, J. Hoefs, G. Menschel, J. Schotr, \& E. Usdowski. 1982. Kinetically controlled variations of major components and carbon and oxygen isotopes in a calcite-precipitating spring. Chemical Geology 36: 299-315. DOI: 10.1016/0009-2541(82)90053-5

Desikachary, T. V. 1987. Atlas of Diatoms. 1st Ed, Madras Science Foundation. Madras, India. $221 \mathrm{p}$.

Dittrich, M. \& S. Sibler. 2010. Calcium Carbonate Precipitation by Cyanobacterial Polysaccharides, In: Pedley, H.M. \& M. Rogerson (Eds.) Tufas and Speleothems: Unravelling the Microbial and Physical Controls. Geological Society of London, Special Publication 336, pp. 51-63. DOI: 10.1144/sp336.4

Drysdale, R., M. P. TAYLOR \& C. IHLENFeLd. 2002. Factors controlling the chemical evolution of travertine-depositing rivers of the Barkly karst, northern Australia. Hydrological Processes 16: 2941-2962. D0I: 10.1002/hyp.1078

FISCHER, H. 1979. Osmotic behavior of diatoms of a hypersaline lake in comparison with tidal diatoms. Nova Hedwigia 64: 251-264.

Flor-Arnau, N., E. Vegas, A. Galan \& J. Cambra. 2008. Red de intercalibracion, red de referencia y red basica de diatomeas en la Cuenca del Ebro. Resultados verano 2008. Informe final 2007-2008. Universitat de Barcelona- Confederacion Hidrografica del Ebro. Barcelona, Catalunya. $146 \mathrm{p}$.

GuIRY, M. D. \& G. M. GuIRY. 2015. AlgaeBase. World-wide electronic publication, National University of Ireland, Galway. http://www.algaebase.org

GRADZINSKI, M. 2010. Factors controlling growth of modern tufa: results of a field experiment. In: Pedley H. M. \& M. Rogerson (Eds.) Tufas and Speleothems: Unravelling the Microbial and Physical Controls. Geological Society Special Publications 336: 143-191. D0I: 10.1144/ sp336.8

Hein, J. R., D. W. Scholl, J. A. Barron, M. G. Jones \& J. Miller. 1978. Diagenesis of late Cenozoic diatomaceous deposits and formation of the bottom simulating reflector in the southern Bering Sea. Sedimentology 25:155-181. D0I: 10.1111/j.1365-3091.1978.tb00307.x

Hudon, C. \& P. Legendre. 1987. The ecological implications of growth forms in epibenthic diatoms. Journal of Phycology 23: 434-441. DOI: 10.1111/j.1529-8817.1987.tb02529.x

Hustedt, F. 1930. Bacillariophyta (Diatomeae). In: A. Pascher (Ed.), Die Stisswasser-Flora Mitteleuropas. Gustav Fischer, Jena. Zweite Auflage. Heft 10. 466 p., 875 Figs.

JACOBSON, R. L.\& E. Usdowski. 1975. Geochemical controls on a calcite precipitating spring. Contributions to Mineralogy and Petrology 51 (1): 65-74. DOl: 10.1007/bf00403513
Jones, B. \& R. W. Renaut. 1996. Morphology and growth of aragonite crystals in hot-spring travertines at Lake Bogoria, Kenya rift valley. Sedimentology 43: 323-340. DOl: 10.1046/j.1365-3091.1996. d01-7.x

Jones, B., R. W. Renaut \& M. R. Rosen. 1998. Microbial biofacies in hotspring sinters: A model based on Ohaaki Pool, North Island, New Zealand. Journal of Sedimentary Research 68: 413-434. D0l: $10.2110 / j s r .68 .413$

Jones, B., C. E. J. De Ronde, R. W. Renaut \& R. B. Owen. 2007. Siliceous sublacustrine spring deposits around hydrothermal vents in Lake Taupo, New Zealand. Journal of the Geological Society of London 164: 227-242. D0I:10.1144/0016-76492005-102

Jones, B., C. E. J. De Ronde \& R. W. Renaut. 2008. Mineralized microbes from Giggenbach submarine volcano. Journal of Geophysical ResearchSolid Earth 113, B08S05: 1-13. D0I: 10.1029/2007jb005482

Kastner, M., J. B. Keene, \& J. M. Gieskes. 1977. Diagenesis of siliceous oozes. I. Chemical controls on the rate of opal-A to opal-CT transformation- an experimental study. Geochimica et Cosmochimica Acta 41:1041-1059. DOI: 10.1016/0016-7037(77)90099-0

Konhauser, K. O., V. R. Phoenix, S. H. Bottrell, D. G. Adams \& I. M. Head. 2001. Microbial-silica interactions in Icelandic hot spring sinter: Possible analogues for Precambrian siliceous stromatolites. Sedimentology 48: 415-433. D0I: 10.1046/j.1365-3091.2001.00372.x

Krumbein, W. E., D. M. Paterson \& G. Zavazin (Eds.) 2003. Fossil and Recent biofilms: a natural history of life on Earth. Kluwer Academic: Dordrecht. 504 p. DOl: 10.1017/s0016756805260776

Lebron, I. \& D. L. Suarez. 1996. Calcite nucleation and precipitation kinetics as affected by dissolved organic matter at $25 \mathrm{C}$ and pH>7.5. Geochimica et Cosmochimica Acta 60: 2767-2776. DOl: 10.1016/0016-7037(96)00137-8

Lojen, S., T. Dolenec, B. Vokal, N. Cukrov, G. Mihelcic \& W. Papesch. 2004. $\mathrm{C}$ and 0 stable isotope variability in recent freshwater carbonates (River Krka, Croatia). Sedimentology 51: 361-375. D0I: 10.1111/j.1365-3091.2004.00630.x

Malusa, J., S. T. Overby \& R. A. Parnell. 2003. Potential for travertine formation: Fossil Creek, Arizona. Applied Geochemistry 18: 10811093. DOI: $10.1007 / \mathrm{s} 10750-009-9791-z$

Merz-Preiß, M. \& R. Riding. 1999. Cyanobacterial tufa calcification in two freshwater streams: ambient environment, chemical thresholds and biological processes. Sedimentary Geology 126: 103-124. D0I: 10.1016/s0037-0738(99)00035-4

Michalopoulos, P., R. C. Aller \& R. J. Reeder. 2000. Conversion of diatoms to clays during early diagenesis in tropical, continental shelf muds. Geology 28: 1095-1098. DOI: 10.1130/0091-7613(2000)28<1095:cod $\operatorname{tcd}>2.0 .00 ; 2$

PedLey, M. 2009. Tufas and travertines of the Mediterranean region: a testing ground for freshwater carbonate concepts and developments. Sedimentology 56: 221-246. DOI: 10.1111/j.1365-3091.2008.01012.x 
Pedley, M, M. Rogerson \& R. Middleton. 2009. Freshwater calcite precipitates from in vitro mesocosm flume experiments: a case for biomediation of tufas. Sedimentology 56: 511-527. D0l: 10.1111/j.13653091.2008.00983.x

Pedley, M. \& M. Rogerson. 2010. Tufas and Speleothems. Unravelling the Microbial and Physical Controls. Geological Society Special Publication No. 336-1. The Geological Society of London, Bath UK. 368 p. DOI: $10.1144 / \mathrm{sp} 336.0$

Pentecost, A. 2005. Travertine. Springer-Verlag, Berlin Heidelberg. 445 p. DOI: $10.1007 / 1-4020-3606-X$

Pinuaga, J. I., E. Garrido \& A. Ramirez. 2004. Geologia, Hidrogeologia y proteccion de los Balnearios de Jaraba (Zaragoza). Anales de la Real Academia Nacional de Farmacia 79: 597-610. ISSN 0034-0618, ISSN-e 1697-4271

RIDING, R. 2000. Microbial carbonates: the geological record of calcified bacterial-algal mats and biofilms. Sedimentology 47 (Supplement 1): 179-214. DOI: 10.1046/j.1365-3091.2000.00003.x

Rogerson, M., M. Pedley, J.D. Wadhawan \& R. Middleton. 2008. New insight into biological influence on the geochemistry of freshwater carbonate deposits. Geochimica et Cosmochimica Acta 72: 49764987. DOI: 10.1016/j.gca.2008.06.030

Round, F. E., R. M. Crawford \& D. G. Mann. 1990. The diatoms. Biology and morphology of the Genera. Cambridge University Press, Cambridge. 758 p. DOI: 10.1016/s0031-9422(00)95245-2

SÁnchez-Castillo, P. M. 1993. Amphora margalefii Tomas var. lacustris P. Sánchez var. nova, a new brackish water diatom. Hydrobiologia 200/201: 475-486. DOI: 10.1007/978-94-017-3622-0_10

Sánchez-Navarro, J. A., P. Coloma \& A. Pérez-Garcia. 2004. Evaluation of geothermal flow at the springs in Aragon (Spain), and its relation to geologic structure. Hydrogeology Journal 12: 601-609. D0l: 10.1007/s10040-004-0330-8

Sancho, C., C. Arenas, G. Pardo, M. Vázquez, J. Hellstrom, J.E. Ortiz, T. Torres, E. RHodes, M. C. OsácaR \& L. AuQué. 2010. Preliminary chronology of the Quaternary tufas from the Piedra River (Iberian Range). Geogaceta 48: 31-34.
Shiraish, F., A. Reimer, A. Bissett, D. De Beer \& G. Arp. 2008. Microbial effects on biofilm calcification, ambient water chemistry and stable isotope records (Westerhofer Bach, Germany). Palaeogeography Palaeoclimatology Palaeoecology 262: 84-99. DOI: 10.1016/j.palaeo.2008.02.011

ShiRAISHI, F., T. OKUMURA, Y. TAKAHASH \& A. KanO. 2010. Influence of microbial photosynthesis on tufa stromatolite formation and ambient water chemistry, SW Japan. Geochimica et Cosmochimica Acta 74: 52895304. DOI: 10.1016/j.gca.2010.06.025

Sмітн, G. M. 1950. Fresh-water algae of the United States. 2nd ed. McGraw-Hill, New York, 719 p. DOI: 10.2307/2421748

Smol, J. P. \& E. F. Stoermer (Eds.). 2010. The Diatoms: Applications for the Environmental and Earth Sciences. 2nd edition, Cambridge University Press, Cambridge. 686 p. ISBN: 9781107564961

Stevenson, R. J., M. L. Bothwell \& R. L. Lowe (Eds.). 1996. Algal ecology: freshwater benthic ecosystems. Academic Press, San Diego CA. 753 p. DOI: $10.2307 / 1313044$

SuAREZ, D. L. 1983. Calcite supersaturation and precipitation kinetics in lower Colorado River, All American canal and east highland canal. Water Resources Research 19: 653-661. D0I: 10.1029/ wr019i003p00653

Vázquez-Urbez, M., C. Arenas, C. Sancho, C. Oscar, L. Auque \& G. Pardo. 2010. Factors controlling present-day tufa dynamics in the Monasterio de Piedra Natural Park (Iberian Range, Spain): depositional environmental settings, sedimentation rates and hydrochemistry. International Journal of Earth Sciences 99 (5): 1027-1049. D0I: 10.1007/s00531009-0444-2

Vázquez-Urbez, M., C. Arenas \& G. Pardo. 2012. A sedimentary facies model for stepped, fluvial tufa systems in the Iberian Range (Spain): the Quaternary Piedra and Mesa valleys. Sedimentology 59 (2): 502-526. DOI: 10.1111/j.1365-3091.2011.01262.x

Recibido: 23 de marzo de 2015.

Aceptado: 15 de abril de 2016. 